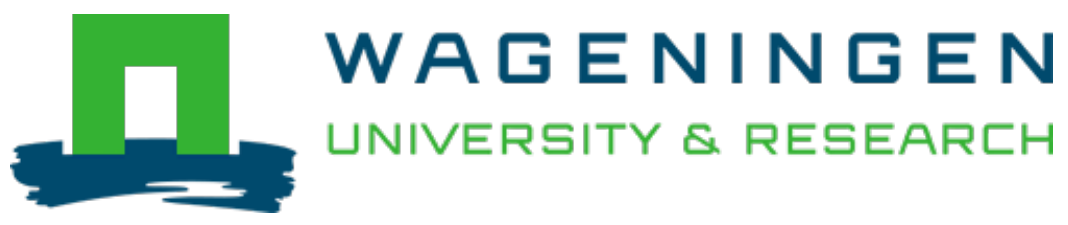

\title{
The political nature of fantasy and political fantasies of nature
}

\author{
Journal of Language and Politics
}

Behagel, J.H.; Mert, Ayşem

https://doi.org/10.1075/jlp.20049.beh

This publication is made publicly available in the institutional repository of Wageningen University and Research, under the terms of article $25 \mathrm{fa}$ of the Dutch Copyright Act, also known as the Amendment Taverne. This has been done with explicit consent by the author.

Article $25 \mathrm{fa}$ states that the author of a short scientific work funded either wholly or partially by Dutch public funds is entitled to make that work publicly available for no consideration following a reasonable period of time after the work was first published, provided that clear reference is made to the source of the first publication of the work.

This publication is distributed under The Association of Universities in the Netherlands (VSNU) 'Article $25 \mathrm{fa}$ implementation' project. In this project research outputs of researchers employed by Dutch Universities that comply with the legal requirements of Article $25 \mathrm{fa}$ of the Dutch Copyright Act are distributed online and free of cost or other barriers in institutional repositories. Research outputs are distributed six months after their first online publication in the original published version and with proper attribution to the source of the original publication.

You are permitted to download and use the publication for personal purposes. All rights remain with the author(s) and / or copyright owner(s) of this work. Any use of the publication or parts of it other than authorised under article $25 \mathrm{fa}$ of the Dutch Copyright act is prohibited. Wageningen University \& Research and the author(s) of this publication shall not be held responsible or liable for any damages resulting from your (re)use of this publication.

For questions regarding the public availability of this publication please contact openscience.library@wur.nl 


\section{John Benjamins Publishing Company}

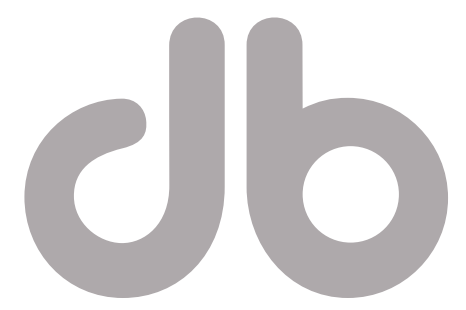

This is a contribution from Journal of Language and Politics 20:1

(C) 2021. John Benjamins Publishing Company

This electronic file may not be altered in any way. The author(s) of this article is/are permitted to use this PDF file to generate printed copies to be used by way of offprints, for their personal use only.

Permission is granted by the publishers to post this file on a closed server which is accessible only to members (students and faculty) of the author's/s' institute. It is not permitted to post this PDF on the internet, or to share it on sites such as Mendeley, ResearchGate, Academia.edu.

Please see our rights policy on https://benjamins.com/content/customers/rights

For any other use of this material prior written permission should be obtained from the publishers or through the Copyright Clearance Center (for USA: www.copyright.com).

Please contact rights@benjamins.nl or consult our website:www.benjamins.com 


\title{
The political nature of fantasy and political fantasies of nature
}

\author{
Jelle Hendrik Behagel and Ayşem Mert \\ Wageningen University $\mid$ Stockholm University
}

\begin{abstract}
Within post-structuralist discourse theory, there has been an ongoing interest in fantasy and the fantasmatic logic. We propose a new way forward and suggest a focus on fantasies of 'nature' and what is deemed 'natural.' Fantasies are structurally entwined with language, desire, and political ontologies. Discourses of nature hold a privileged position in this entwinement. We use the psychoanalytic concept of fantasy to explore how symbolic engagement with the world is supported by fantasmatic mechanisms. We argue that political fantasies express political subjects and objects via the imaginary mechanisms of splitting and projection. In an era of ecological crises and global pandemics, we find that fantasies that create a split between nature and society are a central part of the transformation of political imaginaries and discourses. Studying fantasies of various "naturecultures" and the politics of nature is thus an important new direction for discourse theory to explore anti-essentialist ontologies.
\end{abstract}

Keywords: fantasmatic logics, discourse, phantasy, Anthropocene, natureculture, global pandemic, ecological crisis

\section{Introduction}

For the last fifteen years, post-structuralist discourse theory (PDT) has been in close contact with interpretive policy studies and critical governance scholarship (Behagel et al. 2019). The influence of PDT on political science has grown exponentially after the introduction of the logics approach (Glynos and Howarth 2007), which rendered PDT more accessible to scholars of environmental policy and governance and of ecopolitical movements. Furthermore, PDT has been used and theorised together with Actor Network Theory (Galvin 2011), practice theory (Behagel, Arts, and Turnhout 2019), and feminist and queer approaches (Mallory 2008) to understand the logics of socio-ecological relations and environmental 
governance and ecopolitics, from global (Methmann and Rothe 2012; Mert 2015) to local levels (Griggs and Howarth 2008; Mert 2019). ${ }^{1}$

Fantasy has been employed more scarcely than other PDT concepts in environmental studies. In environmental social sciences, there are few (albeit worthwhile) studies that focus on shared and communal fantasies of nature (e.g. Zoja 1995), or on fantasmatic logics (e.g. Remling 2019). At the same time, fantasies of nature and the natural are a more prevalent topic in environmental humanities and ecocritical studies (e.g. Tsing et al. 2017). One reason for this is the difference in disciplinary traditions. There is a greater interest in environmental political science to study ontic level politics and economic dimensions of ecological degradation and resource use, whereas the philosophical dimensions of what is regarded natural is delegated to other disciplines. Another reason is the tendency of fantasies to be transgressive of established norms, which means that they are not easily studied in formal policy discourses (Glynos 2001).

In the 199os, post-structuralist scholars (including PDT scholars) and political ecologists had formative debates on the possibility of an anti-essentialist framework for investigating the various forms that the natural can take. In After Nature: Steps to an Antiessentialist Political Ecology, Escobar (1999) argued that an anti-essentialist theory of nature entails the simultaneous articulation of the biophysical basis of the concept on the one hand, and its culturally constructed and socially produced dimension on the other. He identified two important intellectual sources for a political ecology that articulates the latter dimension: feminist and post-structuralist political thought. Rather than assuming an unchanging and pre-existing core (i.e. an essence), both theories highlight the constant and differential constitution of identity, its radical openness, and incompleteness. Similar to Laclau, Escobar regards "this critique of essentialism arising out of poststructuralism, the philosophy of language, and hermeneutics as a sine qua non for radical

1. In environmental social studies, discourse analysis has emphasized the importance of the entwinement of meaning with political dynamics and the role of ideology in steering human behaviour (Agrawal 2005; Dryzek 1997; Hajer 1995), offering a much-needed antidote to positivist conceptions of social change and order as motivated by fixed interests and institutional norms. In dialogue with other constructivist and interpretivist approaches, discourse scholars have shown how individual subjects are not rational, profit-maximizing agents and are subject to governmental and individual technologies that shape their desires and agency (Dean 1999; Jasanoff 2004; Epstein 2008). Specifically, PDT has shown how apparently diverse social groups and demands can be articulated in chains of equivalence and challenge hegemonic ideas about environmental politics and policies (Laclau and Mouffe 1985; Griggs and Howarth 2008; Mert 2019). It also highlights how different discourses compete to structure our understanding of the world and the institutional norms and rules we produce to manage it, in environmental politics (Hajer 2005; Behagel and Turnhout 2011; Mert 2015). 
social theory today and for understanding the widening of the field of social struggles" (Escobar 1999, 3).

Today, we argue that the concept of fantasy is critical to move forward and further develop the understanding of nature and environment as inherently contingent and political. Thus, we propose the exploration of fantasies of nature as a way forward for PDT. Recent developments in environmental humanities, particularly the neo-material and post-humanist turns, have provided a fertile ground for this engagement with fantasy. Studying the politics of nature through the concept of fantasy deepens PDT's anti-essentialist ontology and allows for a more purposeful engagement with political ecology, science and technology studies, feminist, queer, and post-human ontologies, within and beyond environmental social science.

Our first goal in this article is to highlight how fantasies are structurally entwined with discourse and meaning, desires and emotions that drive political choices, as well as political ontologies and subjectivities. To do so, we explore the nature of fantasy as well as its political importance by drawing on the Kleinian and Lacanian schools of psychoanalysis (cf. Scott 2016) and more recent literature that highlights the political role of fantasy (Glynos and Stavrakakis 2008; Kapoor 2014; Eberle 2017). Our second goal is to reflect on how discourses of nature and the environment hold a privileged position in this entwinement of language, desire, and being. We argue that this is important, particularly at a time of great dislocations caused by ecological crises and global pandemics. Fantasies of nature, and the relation between natures and cultures, both human and more-thanhuman, are central to analyse the transformation of political imageries and discourses in a time like this.

In what follows, we explore how the concept of fantasy can offer a detailed, specific, and structured exploration of environmental politics and the politics of nature. We believe that in a time of global environmental crisis - including but not limited to climate change, biodiversity loss, inextinguishable wildfires and a pandemic that indirectly relates to each of these problems respectively - the study of fantasy is needed to understand how political processes play out and what drives them. To do this, we start with a review of how fantasy is related to the political and the social in PDT. While much theoretical work has been produced in this context, we largely rely on the works of the Essex School (Laclau and Mouffe 1985; Glynos and Howarth 2007). Then, we turn to psychoanalytical writings that try to explain the central mechanisms by which humans engage with the world (e.g. Klein 1975; Lacan 2002) and explore how the concept of fantasy is used in political studies. As we explain below, fantasy can tell us not just why we cling to unfeasible or unrealistic hopes to maintain a global status quo in an increasingly damaged world, but can also help to identify a repertoire of alternative ways of 
living and being in the Anthropocene (Haraway 2015; Tsing et al. 2017). Fantasies do not only manage desire; they also make worlds.

\section{Fantasy in PDT}

From whence come the political discourses that are articulated, compete to structure social norms and institutions, and - when successful - shape human agency and desire? In PDT, the role of fantasy has been central in explaining the ideological force of a discourse, i.e. how and (particularly) why ideology grips the political subject. Based on Lacan's conception of jouissance, it is understood that 'the imaginary promise of recapturing our lost/impossible enjoyment provides the fantasy support' for our political and social choices (Stavrakakis 2005; 73-74). Political projects and ideologies promise the delivery of this fullness, often first by identifying an obstacle to it (an 'other' that stands in the way) and then suggesting its removal. However, even when the political project is victorious, the promise is only partially fulfilled; soon after, social antagonisms return, and the individual subjects' incompleteness is yet again revealed. To cover this impossibility of capturing full enjoyment, political fantasies structure the individual's partial enjoyment through various rituals and through the use of a utopian and dystopian narratives which reproduces the fantasy both in official and unofficial public discourse (Glynos and Stavrakakis 2008, 262).

Arguing for a central role of the study of fantasy in PDT, Glynos and Howarth (2007) consider the "fantasmatic" as a bridge between social and political dynamics. Specifically, they use a logics approach to explain the role of fantasy. Political logics are active when meaning becomes fluid and when one discursive element starts determining the meaning of others. Next, social logics represent how differentiation between discursive elements fixes meaning and protects these elements from overdetermination and thus from making meaning fluid. Fantasmatic logics represent the vector, or the energy behind, such dynamics of making things fluid or fixed (Glynos 2008). Thus, a fantasmatic logic may defend social identities against the fluidity of politicisation that represent a threat to their continuity as partial enjoyment is structured by specific fantasies. Alternatively, a fantasy may also be part of fantasmatic logics that steer towards fluidity of meaning, as it promises full enjoyment to be attained through a political project or ideology (Glynos and Stavrakakis 2008)

In PDT, fantasies can thus be understood to defend against or push towards the politicisation of discourses through maintaining social identities and/or by subversion of such identities. What distinguishes a fantasmatic narrative from a non-fantasmatic one is its entwinement with desire and quality of (potential) 
transgression (Eberle 2017). This is critical in distinguishing if a narrative is fantasmatic, as Glynos and Stavrakakis $(2008,263)$ also note,

[fantasy] links the "dry" socio-symbolic field (through a reference to its official insignia) to the "sticky" affects of the subject. This suggests that identifying a narrative as a specifically fantasmatic narrative, involves homing in on the affective investment made in one or more of its elements, as well as the subject's transgressive relation to an officially affirmed ideal.

In sum, fantasmatic narratives move beyond only discursive or symbolic content: they are entwined with desire, have the tendency to be transgressive of social and political norms, and can subvert identities.

\section{Fantasy in psychoanalysis}

In his treatment of the concept of fantasy, Lacan makes multiple references to Klein. Specifically, he values Klein for exploring the subject and identification in the unconscious. Lacan considers the "controversial discussions" of the 1940s, when it was debated whether fantasy is unconscious (position held by the Klein faction) or (pre-)conscious (position held by the Vienna faction of Anna Freud), solved by arguing that the unconscious fantasy of Klein can be recognised as an "an image set to work in the signifying structure" (Lacan 2002, 532). ${ }^{2}$ He thus moves fantasy to the realm of the Imaginary, but still draws on Klein to link the concept of fantasy to the subject. The quote below is a good illustration:

Only the antidialectical mentality of a culture which [...] tends to reduce all subjective activity to the being of the ego, can justify the astonishment of a Von den Steinen when confronted by a Bororo who says: 'I'm an ara'. (Lacan 2002, 25)

When, in the 19th century, the anthropologist von den Steinen visited the Bororo tribe in the Brazilian Amazon, he understood the statement "I am an ara" to mean that members of the tribe consider themselves to be red parrots. Thus, the Bororo are simultaneously red parrots and people (Smith 1972). According to Lacan (2002), von den Steinen's astonishment with this dual identity stems from not

2. We prefer to write 'fantasy' over 'phantasy' since the latter is often linked to the Kleinian concept of phantasy as unconscious and prelinguistic, where imagination and reality are not yet differentiated. While we are indebted to Klein in our understanding of fantasy, we follow Lacan (and not Anna Freud) in his conceptualization of fantasy and the English versions of his texts in our spelling of the word. Our concern is moreover social and political, where we can assume linguistic expression of the fantasies in question. 
being able to allow contradictions and instability to exist within a single understanding of the world. The latter considers the subject as single and unchanging, whereas Lacan (2002) considers the subject as split and 'barred' from fully grasping itself, due to a fundamental lack that is inscribed in the subject in the mirror stage of development. In this mirror stage, the infant grasps itself as an outer image that at the same time gives permanence to its inner life. The image of the self in the mirror is thus (1) formative of the subject and (2) establishes "a relationship between an organism and its reality - or, as they say, between the Innenwelt and the Umwelt" (Lacan 2002, 78). Accordingly, Lacan $(2002,96)$ argues that proclaiming oneself a parrot is not much different than saying "I am a scientist" or "I am a man".

Lacan's story about red parrots and his insights about the mirror stage point to a specific understanding of fantasy, namely that our engagement with the world is mediated by a fundamental fantasy (Miller 1992; Glynos 2018). Lacan is moreover indebted to Klein for the idea that fantasies are constitutive of the subject.

Klein and Isaacs assume that phantasies are not used solely to express unconscious impulses and wishes. Mechanisms of defence too are expressed through phantasy. Projection, introjection, splitting, idealisation, denial, repression are abstract terms that describe general psychic processes, but a given individual's use of them is expressed through a particular phantasy.

(Spillius 2001, 367)

Klein and Lacan share the understanding that fantasies are expressions of mechanisms of splitting - between self and the world - and mechanisms of projection attributing inner feeling of anxiety and joy to outer objects. Both mechanisms, according to Klein (1975), are mediated by instinct, whereas Lacan connects these mechanisms to the functioning of the Imaginary. Accordingly, our symbolic engagement with the world is always accompanied by imaginary mechanisms that involves the splitting of the subject itself and splitting between inner and outer objects, including the projection of inner objects on outer objects or introjection of outer objects on inner objects. These mechanisms of splitting and projection also explain the strong emotions of aggression and joy that are connected to fantasmatic operations.

The position that our engagement with the world is fundamentally fantasmatic does not mean that we cannot distinguish between fantasy and reality. Without question, fantasy and reality each have a distinct quality, and each follow different lines of development. However, in the words of Isaacs $(1948,109)$ :

reality-thinking cannot operate without concurrent and supporting unconscious phantasies; e.g. we continue to 'take things in' with our ears, to 'devour' with our eyes, to 'read, mark, learn and inwardly digest', throughout life. 
What Isaacs writes implies that meaning is overdetermined: there is never just one single instinct or experience that is responsible for stirring up the subject's mental, emotional, or affective life. Rather, experiences of the outer world are always mixed with inner movements; instincts and emotions are shaped and reshaped by each experience; and mental processes combine rational thought with the unconscious. Accordingly, fantasies can be adjusted to fit experience and develop over time.

\section{Political fantasies}

How do we move from the individual to the political subject? Or, what makes fantasies political? We argue that in principle the difference between a fantasy of a single person or of a "people" can only be known after analysis. Specifically, a fantasy is political when it includes the splitting between a political object and a political subject, thereby constituting both in the domain of politics. To identify a political fantasy in practice, we may ask if we can find discourse in the public domain that is entwined with desire and emotion, and that also shows traces of imaginary mechanisms of splitting and projection (i.e. if we can identify an "image set to work in the discourse"). In that case, political fantasies are expressed in specific discourses that connect specific ideas to public anxiety, aggression, or joy. The mechanisms of projection and splitting can moreover be seen to be expressed in the transgression of norms or in strong antagonisms. A political fantasy can thus be recognised for having a 'black and white' character that leaves little space for ambiguity (Eberle 2017), or a discourse may include 'good' and 'bad' political objects that are very one-dimensional.

Many fantasy studies in PDT emphasize the importance of fantasy in maintaining the identity of a political subject in the absence of a continuous external object by which it can define itself. Arfi (2010) for example explains that scholarship of international politics itself employs a fantasy of states as autonomous actors with stable interests to be able to study the 'state' as a political subject. Eberle (2017), when studying German opposition to the Iraq war, explains the important role of fantasy in providing "ontological security", with Germany as the rational state that opposes war versus the "irrational" American leadership of G. W. Bush. Salter and Dickinson (2020), in their exploration of healthy food discourse in New Zealand, explain how the fantasmatic quality of that discourse promises a "subject without lack", by polarising "good" and "bad" food. Gunder (2015) also highlights the function of fantasy to simplify the world. Doing so, fantasies cover up the primordial lack that is proper to the human condition. He also emphasizes that fantasies are rearticulated repeatedly to support the same political discourse. This explains why public policies are rearticulated in new words in regular intervals. 
Political fantasy studies in the tradition of Lacanian psychoanalysis (but not in the tradition of PDT) tend to focus less on the political subject and more on the connection of ideology with desire, anxiety, and joy. Fletcher (2018), for example, explains how a strong neoliberal ideology in climate change discourses is supported by fantasmatic structures such as 'sustainable cities' or 'getting the market right. He argues that neoliberal ideology functions as it does because its supporting fantasies give subjects a small taste of joy in the context of an unattainable promise of full enjoyment (jouissance). Fletcher argues that these fantasies draw heavily on mechanisms of denial (or repression) by only acknowledging part of reality or half-truths. He then advocates for adopting a depressive position of mourning in order to escape the strong grasp of fantasy on reality and to be able to address issues such as climate change from a more realistic perspective. Kapoor (2014), in an introduction to a special issue on psychoanalysis and development, more generally describes how fantasy can be used to connect political economy to desire and emotions. The lesson he draws from fantasy studies is that the mobilisation of desire is a powerful explanation for how the status quo is maintained in a political economy of development.

In summary, political fantasies support the making of political subjects and objects, while they can be recognised by how they mobilise desire and emotions via imaginary mechanisms of splitting and projecting. While all agree that fantasy should be studied as the link between discourse and desire, we observe that qualities of fantasy that include providing ontological security and transgressions of norms (Eberle 2017) are not taken on board by all authors. More importantly, we argue that these latter qualities give us insight into imaginary mechanisms of fantasy of splitting and projection, as described by Klein, Lacan, and others. Tracing and studying these mechanisms provide crucial insights into political subject formation and can be made more central to fantasy studies. Importantly, these imaginary mechanisms of fantasy give shape to how we relate to nature, as explained below.

\section{Fantasies of nature}

Nature! We are surrounded and embraced by her: powerless to separate ourselves from her, and powerless to penetrate beyond her.

(Goethe, cited in Huxley 1869, 9)

The opening quote of the first issue of the journal Nature, cited above, expresses a fantasy of how 'we' - as humanity - relate to nature. Once we shift our perspective from the romanticism of Goethe to the political study of fantasy, we 
observe how the quote makes explicit reference to the mechanism of splitting, by referring to the impossibility of making a complete break between us and the outside world ('powerless to separate'). We can also observe projection mechanisms, in the positive attribution of nature's embrace, and feelings of powerlessness to establish ourselves as an autonomous subject. It is not just Goethe who uses such words: fantasies about humanity's place in nature and possibilities to control nature underlie ideologies and mythologies across the world, with important differences in their description of this place and power.

Descola (2013) argues that how we imagine our relationship with nature is at the heart of the ontologies by which we order and make sense of the world. Conceptually, he draws out a basic scheme of four ways to relate to nature: we can consider nature to have an inner life or soul, like our own, but a different outer form (animism); to have a similar form to our own, both in appearance and in soul (totemism); to be similar to us on the outside but different on the inside (naturalism); or to be different both in our inner experience and our outside manifestation (analogism/modernism) (Descola 2013, 122). According to this scheme, the way in which the split between nature and society is made, follows the establishment of relations between subject and objects, just like the imaginary splitting that occurs in fantasy. Thus, Descola shows that understanding ourselves as distinct and separate from nature is not given, but the result of a particular fantasy instituted through culture. We can find many (non-modern, non-western) cultures that are in-the-world very differently.

That the split between nature and society is fantasmatic means that it is both contingent and never complete. As fantasy is articulated in discourse and adapts to experience, the distinction between nature and society is never final. Given the above debate about political fantasies, we may expect to find many political fantasies that nonetheless seek to attribute a final character to this distinction. In We have never been modern, Latour (1993) explores this theme. He argues that we moderns symbolically construe objects as either natural or social, even when in practice they are never fully cultural or fully natural, but hybrids. He thus awards fantasmatic quality to modernity and argues that the modern separation between nature and culture simply supports our abilities to engage with the world. In particular, he argues, it allows us to cross ecological and social boundaries, to produce objects and networks, and to become global. "Global nature" is thus the result of a political fantasy that produces nature as an object of desire that is distinct and separate from society. Accordingly, nature may either give political subjects joy in "small doses" as it appears and disappears (cf. Fletcher 2018) or it may cause anxiety and aggression as it is stolen away (cf. Daly 1999).

Let us offer an example of a global fantasy of nature. In 2019, there was a $77 \%$ year-to-year increase in the Amazonian wildfires compared to the earlier tracking 
period, resulting in a media uproar, and international calls to the Brazilian government to take action. A month after the internet meme "the Amazon is burning" went viral, the Brazilian government was broadcasting advertisements on digital media (e.g. on Youtube) that presented Brazil as a sustainable country that uses clean energy and takes care of its nature. During this period, Brazilian president Bolsonaro had accused international NGOs of using the media attention to claim the Amazon for themselves so that they could mine valuable resources, and even accused them of starting the fires (Watts 2019). At the same time, stories in the global media about the Amazon rainforest being the lungs of the earth were debated, debunked, and reaffirmed. As such, persecution fantasies (NGOs stealing Brazilian resources) were mixed and started competing with fantasies that draw on simple repression mechanisms (Brazil as a sustainable country) or connect anxiety to images of catastrophe (the Amazon turning into a desert).

Beyond their narrative content, these fantasies mobilise different desires and emotions. Whereas the fantasy of "the Amazon is burning" mobilises anxiety over the loss of a global resource and carbon sink, the fantasy of international NGOs stealing the Amazon from Brazil mobilises aggression. Splitting and projection mechanisms can also be identified in these fantasmatic discourses. The perceived wilderness of the Amazon is a global heritage of humanity, which can only be preserved with the cultured socio-economic practices of sustainable consumption. The absurd presentation of Brazil as a country that produces such sustainable products intervenes in this fantasy of conserving and consuming the Amazon in the global public opinion, while Bolsonaro's Brazil at the same time continues to aggressively pursue commodity production for global trade.

The Amazon example is one of many where nature plays a key role in the articulation of political discourse and political identity. In these discourses, emotions and affect play a central role. These can be emotions of anxiety and loss, but also of joy and exuberance, when nature is celebrated as close to human nature, or as offering services or gifts to people. Other fantasies establish clear linkages between human action and nature conservation or loss. For example, the fantasy of setting aside half the world's surface for conservation, called "Half-Earth" (Wilson 2016) reveals the impossibility of political action and inertia at once: Humanity's survival depends on an impossible scheme that separates wilderness from culture and society, and forms a human identity as a universal. On the other hand, this idea was heavily critiqued for not allowing (disprivileged) humans to enjoy those protected areas (Büscher et al. 2017) for their current needs and survival. Understanding such fantasies can shed light on what drives political actions to conserve nature, to extract and destroy it, or to find new ways of being and living with nature. 


\section{Political fantasies in the Anthropocene}

The age of the Anthropocene highlights the need to think about nature and culture as entwined. Understanding how fantasmatic mechanisms of splitting and projecting steer anxiety and joy are fundamental to that effort. Anna Tsing and colleagues (2017), Donna Haraway (2015), and others (Yusoff 2018) argue that the meaning of the Anthropocene is not settled, and that we live in a fluid moment in which multiple futures and worlds are still possible. These possible worlds range from the Plantationocene where agricultural monocropping has overtaken global landscapes to the Chthulucene were new relationships with nature have established new and diverse "naturecultures" (Haraway 2015). Some of these futures involve new relationships between human and non-human agents - the making of kin - and can be viewed as an affirmative articulation of the Anthropocene, an artful way of being in the world. The Anthropocene thus calls for an exploration of fantasies that moves beyond analysing established cultural tropes and that can explore ontologies that move beyond 'global nature'.

The positive potential of political fantasies to bring about new worlds may not be self-evident in a time of fake news and multiple crises. It is tempting to consider the concept of fantasy as perhaps instructive for pointing out the human tendency to deceive and cover up truths, but to be less enthusiastic about awarding it an affirmative role in human experience. Indeed, Swyngedouw and Ernstson (2018) argue that the idea of the Anthropocene itself is a fantasy that hides and smooths over political antagonisms and is therefore obscene. They are suspicious of the increasingly central role of nature in political struggles and argue instead for a return to the 'real' of the social. While fantasies indeed often draw on obscenity to unsettle and allow for new ways of splitting between subject and object, dismissing fantasies as unreal carries the risk of supporting those political discourses already in power. An attempt at a planetary politics from a posthuman perspective (see Burke et al. 2016), in which the divide between human and nature is redrawn with a softer pencil, is - in our eyes - more hopeful.

\section{Conclusion}

Our argument for the importance of studying political fantasies of nature, especially in the Anthropocene, is driven by the belief that PDT is especially well suited to engage in this endeavour, with its focus on political subjects and fantasmatic logics (Glynos and Howarth 2007). We highlight three dimensions of fantasy that we consider most relevant for this endeavour and represent important avenues for further study: 
- The discursive content of political fantasy that gives expression to the desires, emotional investments, and imaginary mechanisms at play. Such content can include strong moral judgements, black-and-white thinking, transgression of social and political norms, and more.

- The entwinement of political fantasy with emotions and desire, and specifically with anxieties and enjoyment related to nature.

- The relation between the political subject and its object, including how "naturecultures" are split in separate elements.

Political fantasies of nature shield our political discourse from total dislocation and a complete unravelling of meaning. They also steer our anxieties and joys in ways that prevent total breakdown or social psychosis. They are therefore a necessary element of planetary politics and it is worth exploring both the positive and negative roles that fantasy can play in responses to the great dislocations caused by ecological crises and global pandemics. Such a political project starkly contrasts with proposing techniques of mindfulness and meditation (cf. Wamsler and Brinks 2018), which is too often still the first response to emotional distress caused by planetary crises. In contrast, fantasies support an ethics of joy, an ontological form of pacifism towards human and non-humans that is required for ecological justice and a posthuman ethics (Braidotti 2018). Different fantasies of various "naturecultures" moreover can imagine different futures, effectively changing ontological stances, epistemological preferences, political imaginaries and social practices. From a both a democratic and a posthuman viewpoint, the acknowledgement of a multitude of political fantasies is therefore desirable.

\section{Acknowledgements}

This article has been inspired by conversations we have had with colleagues who took part in The Hauntological Turn Research Seminar at Wageningen University, Imagining the Anthropocene panel at the Earth System Governance Conference hosted by the National Autonomous University of Mexico, and Fantasy beyond Logics panel at the International Conference in Ideology and Discourse Analysis at Essex University. We would like to specifically thank Jason Glynos, Eric Swyngedouw, Eva Lövbrand, Laura Horn, Rob Fletcher, Katja Freistein, and JLP's anonymous reviewers for their helpful and constructive feedback. The writing of this article has benefitted from funding provided by FORMAS (Swedish Research Council for Sustainable Development) under the National Research Programme on Climate (Contract: 2017-01962_3). 


\section{References}

Agrawal, Arun. 2005. "Environmentality: Community, Intimate Government, and the Making of Environmental Subjects In Kumaon, India." Current Anthropology 46 (2): 161-19o. https://doi.org/10.1086/427122

Arfi, Badredine. 2010. "Fantasy in the Discourse of 'Social Theory of International Politics'." Cooperation and Conflict 45 (4): 428-448. https://doi.org/10.1177/0010836710387098

Behagel, Jelle Hendrik, Bas Arts, and Esther Turnhout. 2019. "Beyond Argumentation: A Practice-Based Approach to Environmental Policy." Journal of Environmental Policy \& Planning 21 (5): 479-491. https://doi.org/10.1080/1523908X.2017.1295841

Behagel, Jelle Hendrik, and Esther Turnhout. 2011. "Democratic Legitimacy in the Implementation of the Water Framework Directive in the Netherlands: Towards Participatory and Deliberative Norms?" Journal of Environmental Policy \& Planning 13 (3): 297-316. https://doi.org/10.1080/1523908X.2011.607002

Braidotti, Rosi. 2018. "Ethics of Joy." In Posthuman Glossary, edited by Rosi Braidotti and Maria Hlavajova, 220-224. Bloomsbury Publishing.

Burke, Anthony, Simon Fishel, Audra Mitchell, Simon Dalby, and Daniel J. Levine. 2016. "Planet Politics: A Manifesto from the End of IR." Millennium 44 (3): 499-523. https://doi.org/10.1177/0305829816636674

Büscher, Bram, Robert Fletcher, Dan Brockington, Chris Sandbrook, William M. Adams, Lisa Campbell (a4), Catherine Corson, Wolfram Dresslerf, Rosaleen Duffy, Noella Gray, George Holmes, Alice Kelly, Elizabeth Lunstrum, Maano Ramutsindela and Kartik Shanker. 2017. "Half-Earth or Whole Earth? Radical Ideas for Conservation, and their Implications." Oryx 51 (3): 407-410. https://doi.org/10.1017/S0030605316001228

Daly, Glyn. 1999. "Ideology and its Paradoxes: Dimensions of Fantasy and Enjoyment." Journal of Political Ideologies 4 (2): 219-238. https://doi.org/10.1080/13569319908420796

Dean, Mitchell. 1999. Governmentality: Power and Rule in Modern Society. London: SAGE.

Descola, Philippe. 2013. Beyond Nature and Culture. University of Chicago Press. https://doi.org/10.7208/chicago/9780226145006.001.0001

Dryzek, John S. 1997. The Politics of the Earth: Environmental Discourses. Oxford University Press.

Eberle, Jakub. 2017. "Narrative, Desire, Ontological Security, Transgression: Fantasy as a Factor in International Politics." Journal of International Relations and Development 22 (1): 243-268. https://doi.org/10.1057/s41268-017-0104-2

Epstein, Charlotte. 2008. The Power of Words in International Relations: Birth of an AntiWhaling Discourse. MIT Press. https://doi.org/10.7551/mitpress/9780262050920.001.0001 Escobar, Arturo. 1999. "After Nature: Steps to an Anti-essentialist Political Ecology." Current Anthropology 40 (1): 1-30. https://doi.org/10.1086/515799

Fletcher, Robert. 2018. "Beyond the End of the World: Breaking Attachment to a Dying Planet", in Psychoanalysis and the Global, edited by Ilan Kapoor, 48-69. Lincoln: University of Nebraska Press. https://doi.org/10.2307/j.ctv47w9gt.9

Galvin, Raymond James. 2011. Discourse aAnd Materiality in Environmental Policy: The Case of German Federal Policy on Thermal Renovation of Existing Homes. PhD Diss., University of East Anglia.

Glynos, Jason, and David Howarth. 2007. Logics of Critical Explanation in Social and Political Theory. New York: Routledge. https://doi.org/10.4324/9780203934753 
Glynos, Jason, and Yannis Stavrakakis. 2008. "Lacan and Political Subjectivity: Fantasy and Enjoyment in Psychoanalysis and Political Theory." Subjectivity 24 (1): 256-274. https://doi.org/10.1057/sub.2008.23

Glynos, Jason. 2001. "The Grip of Ideology: A Lacanian Approach to the Theory of Ideology." Journal of Political Ideologies 6 (2): 191-214. https://doi.org/10.1080/13569310120053858

Glynos, Jason. 2008. "Ideological Fantasy at Work." Journal of Political Ideologies 13 (3): 275-296. https://doi.org/10.1080/13569310802376961

Glynos, Jason. 2018. "Theory and Evidence in the Freudian Field: From Observation to Structure." In Lacan And Science, edited by Jason Glynos and Yannis Stavrakakis, 13-50. New York: Routledge. https://doi.org/10.4324/9780429476501-2

Griggs, Steven, and David Howarth. 2008. "Populism, Localism and Environmental Politics: The Logic and Rhetoric of the Stop Stansted Expansion Campaign." Planning Theory 7 (2): 123-144. https://doi.org/10.1177/1473095208090431

Gunder, Michael. 2015. “The Role of Fantasy in Public Policy Formation.” In Evolutionary Governance Theory, edited by Raoul Beunen, Kristof Van Assche, and Martijn Duineveld, 143-154. Cham: Springer.

Hajer, Maarten A. 2005. "Coalitions, Practices, and Meaning in Environmental Politics: From Acid Rain to BSE." In Discourse Theory in European Politics, 297-315. London: Palgrave Macmillan. https://doi.org/10.1057/9780230523364_13

Hajer, Maarten A. 1995. The Politics of Environmental Discourse: Ecological Modernization and the Policy Process. Oxford: Clarendon Press.

Haraway, Donna. 2015. "Anthropocene, Capitalocene, Plantationocene, Chthulucene: Making Kin.” Environmental Humanities 6 (1): 159-165. https://doi.org/10.1215/22011919-3615934

Huxley, Thomas H. 1869. "Nature: Aphorisms by Goethe." Nature 1: 9-11. https://doi.org/10.1038/001009ao

Isaacs, Susan. 1948. "The Nature and Function of Phantasy." International Journal of PsychoAnalysis 29: 73-97.

Jasanoff, Sheila (ed.). 2004. States of Knowledge: The Co-Production of Science and the Social Order. New York: Routledge. https://doi.org/10.4324/9780203413845

Kapoor, Ilan. 2014. "Psychoanalysis and Development: An Introduction." Third World Quarterly, 35 (7): 1117-1119. https://doi.org/10.1080/01436597.2014.926099

Klein, Melanie. 1975. Envy and Gratitude. And Other Works 1946-1963. London: The Hogarth Press.

Lacan, Jacques. 2002. Ecrits: A Selection. New York: Routledge.

Laclau, Ernesto, and Chantal Mouffe. 1985. Hegemony and Socialist Strategy: Towards a Radical Democratic Politics. London: Verso.

Latour, Bruno. 1993. We Have Never Been Modern. Harvard: Harvard University Press.

Mallory, Chaone. 2008. "Ecofeminism and a Politics of Performative Affinity: Direct Action, Subaltern Voices, and the Green Public Sphere." Ecopolitics Online Journal 1 (2): 2-13. https://doi.org/10.1108/S2041-806X(2008)0000002002

Mert, Ayşem. 2019. "Participation(s) in Transnational Environmental Governance: Green Values versus Instrumental Use.” Environmental Values 281 (1): 101-121. https://doi.org/10.3197/096327119X15445433913596

Mert, Aysem. 2015. Environmental Governance through Partnerships. Cheltenham: Edward Elgar. https://doi.org/10.4337/9781782540052 
Methmann, Chris, and Delf Rothe. 2012. "Politics for the Day after Tomorrow: The Logic of Apocalypse in Global Climate Politics.” Security Dialogue 43 (4): 323-344. https://doi.org/10.1177/0967010612450746

Miller, Jacques-Alain. 1992. "Duty and The Drives." Newsletter of The Freudian Field, 6 (1/2): 5-15.

Remling, Elise. 2019. "Adaptation, now? Exploring the Politics of Climate Adaptation through Poststructuralist Discourse Theory." PhD diss., Södertörn University.

Salter, Leon and Andrew Dickson. 2020. "The Fantasy of Healthy Food: Desire and Anxiety in Healthy Food Guide Magazine." Critical Public Health, https://doi.org/10.1080/09581596.2020.1724262

Scott, Bruce. 2016. “The New Klein-Lacan Dialogues." European Journal of Psychotherapy \& Counselling. 18 (4): 427-430. https://doi.org/10.1080/13642537.2016.1260679

Smith, Jonathan Z. 1972. "I Am a Parrot (Red)." History of Religions 11 (4): 391-413. https://doi.org/10.1086/462661

Spillius, Elizabeth Bott. 2001. "Freud and Klein on the Cooncept of Phantasy." The International Journal of Psychoanalysis 82 (2): 361-373. https://doi.org/10.1516/5PWR-57TK-VT2U-3XU8

Stavrakakis, Yannis. 2005. "Passions of Identification: Discourse, Enjoyment, and European Identity." In Discourse theory in European politics, 68-92. London: Palgrave Macmillan. https://doi.org/10.1057/9780230523364_3

Swyngedouw, Erik, and Henrik Ernstson. 2018. "Interrupting the Anthropo-Obscene: Immuno-Biopolitics and Depoliticizing Ontologies in the Anthropocene." Theory, Culture and Society 35 (6):3-30. https://doi.org/10.1177/0263276418757314

Tsing, Anna, Heather Swanson, Eliane Gan, and Nils Bubandt, eds. 2017. Arts of Living on a Damaged Planet: Ghosts and Monsters of the Anthropocene. Minneapolis: University of Minnesota Press.

Wamsler, Christina, and Ebba Brink. 2018. Mindsets for Sustainability: Exploring the Link Between Mindfulness and Sustainable Climate Adaptation. Ecological Economics 151: 55-61. https://doi.org/10.1016/j.ecolecon.2018.04.029

Watts, Jonathan. 2019. "Jair Bolsonaro Claims without Evidence that NGOs are Setting Fires in Amazon Rainforest". The Guardian, August 21, 2019.

Wilson, Edward. O. 2016. Half-Earth: Our Planet's Fight for Life. New York: WW Norton and Company.

Yusoff, Kathryn. 2018. A Billion Black Anthropocenes or None. Minneapolis: U of Minnesota Press. https://doi.org/10.5749/9781452962054

Zoja, Luigi. 1995. Growth and Guilt: Psychology and the Limits of Development. London: Psychology Press. 


\section{Address for correspondence}

Jelle Hendrik Behagel

Forest and Nature Conservation Policy Group

Wageningen University

P.O. box 47

6700 AA Wageningen

The Netherlands

jelle.behagel@wur.nl

\section{Biographical notes}

Jelle Behagel is Assistant Professor at the Forest and Nature Conservation Policy Group of Wageningen University the Netherlands. His research focuses on the politics of forest and nature, from global to local levels. Jelle is also associate editor of Environmental Science \& Pol$i c y$, coordinator of a special Master track on Sustainable Development Diplomacy, and chair of the WUR council.

(iD) https://orcid.org/oooo-0002-3997-3446

Ayşem Mert is Associate Professor at the Political Science Department of Stockholm University and a member of Shadow Places and Earth System Governance Networks. She uses poststructuralism, discourse theory and critical approaches to study discourses of democracy and environment in the Anthropocene, public-private cooperation in sustainability governance, and the post-corona world order. She is the editor of Earth System Governance Working Papers, and the author of Environmental Governance through Partnerships A Discourse Theoretical Study (Edward Elgar).

\section{Publication history}

Date received: 9 November 2019

Date accepted: 5 November 2020

Published online: 18 December 2020 